\title{
Influence of Vegetation Characteristics on Nutrient Loss in the Rainforest Belt of Agoi- Ekpo, Cross River State, Nigeria
}

\author{
1*IWARA, AI; ${ }^{2}$ NJAR, GN; ${ }^{3}$ OGUNDELE, FO; ${ }^{4}$ TOKULA, AE \\ ${ }^{* 1}$ Department of Geography and Environmental Management, University of Abuja. \\ ${ }^{2}$ Department of Geography and Environmental Science, University of Calabar. \\ ${ }^{3}$ Department of Geography and Planning, Lagos State University. \\ ${ }^{4}$ Department of Geography and Environmental Studies, Kogi State University Anyigba. \\ *Correspondence: iwaradream2008@gmail.com; Tel.: +2348039451970
}

\begin{abstract}
The study evaluated the influence of vegetation characteristics on nutrient loss in vegetation fallows in a part of the rainforest belt in Agoi-Ekpo, Cross River State. Participatory method was used to identify fallows of 3-year and abandoned farmland. In each identified fallow category, 10 plots for vegetation estimation was established, while two runoff plots of $10 \mathrm{~m} \mathrm{x} 4 \mathrm{~m}$ was constructed and used for nutrient loss estimation. Data was gathered during the cropping season of March to November, 2012. Results showed that on the 3-year fallow only basal cover was retained by the model and significantly explained $\mathrm{Ca}$ loss $\left(\mathrm{R}^{2}=0.627, \mathrm{~F}=3.655, \mathrm{p}<0.01\right), \mathrm{Mg} \operatorname{loss}\left(\mathrm{R}^{2}=0.57 .2, \mathrm{~F}=3.271, \mathrm{p}<0.05\right)$ and potassium loss $\left(\mathrm{R}^{2}=0.527, \mathrm{~F}=2.980, \mathrm{p}<0.05\right)$. On the abandoned farmland, the model retained only crown cover and it significantly explained OC loss $\left(\mathrm{R}^{2}=0.591, \mathrm{~F}=3.402, \mathrm{p}<0.01\right), \mathrm{TN}\left(\mathrm{R}^{2}=0.599, \mathrm{~F}=3.456, \mathrm{p}<0.01\right), \mathrm{Ca}\left(\mathrm{R}^{2}=0.674, \mathrm{~F}=4.067, \mathrm{p}<0.01\right)$, $\operatorname{Mg}\left(R^{2}=0.796, F=5.75, p<0.01\right)$ and $K\left(R^{2}=0.823, F=6.090, p<0.01\right)$. The study showed that more nutrient element losses were recorded in the abandoned farmland. The study suggests that trees and shrubs should not be completely cut down on farmlands facilitate rapid vegetation restoration during land abandonment.
\end{abstract}

\section{DOI: https://dx.doi.org/10.4314/jasem.v22i7.8}

Copyright: Copyright $\odot 2018$ Hamid et al. This is an open access article distributed under the Creative Commons Attribution License (CCL), which permits unrestricted use, distribution, and reproduction in any medium, provided the original work is properly cited.

Dates: Received: 09 April 2018; Revised: 30 May: 2018; Accepted: 11 June 2018

Keywords: Nutrient loss, Vegetation characteristics, multiple regression, fallow

Vegetation parameters such as crown cover, herbaceous composition and cover, tree density, species composition, tree height, tree size, and basal cover play vital roles in protecting the soil from the direct impact of raindrop as well as help to slow down the movement of surface runoff and allow rainwater to infiltrate the soil (Iwara, 2014; Iwara et al., 2017). Herbaceous cover limits runoff by providing a physical barrier, which also increases the chance for runoff to infiltrate. Vegetative cover also serves as a filter to increase the removal of particles from runoff (Iwara et al., 2017; Iwara and Ewa, 2018). Ground cover can be present in the form of living plants or as residue from the previous crop. Vegetation and herbaceous cover have several important effects on rainfall and runoff water: herbaceous cover reduces the impact of raindrops on the soil by intercepting raindrops and absorbing much of the energy. The ability of vegetation parameters to suppress nutrient element loss depends on the type of vegetation and age of fallow. For this reason, vegetation composition and structure carry out diverse functions in protecting the soil from the direct impact of raindrops, hold back the movement of surface runoff and allow rainwater to get into the soil. It is also a source of nutrients to the soil
(Puigdefábregas, 2005; Wei et al., 2007; VásquezMéndez et al., 2010; Iwara and Ewa, 2018). The establishment of dense canopy cover and high density of plant during fallow or vegetation restoration help in enhancing the effectiveness of vegetation cover to suppress runoff (Ali et al., 2007).

Despite the essential role vegetation plays in soil erosion control, studies that examined the influence of a set of vegetation parameters on nutrient loss especially during fallowing are poorly documented in the literature. This therefore makes the present study justifiable and a necessity mostly in the present era of climate change and rapid reduction in fallow periods as a result of the continuous increase in human population. Available studies on soil erosion and nutrient losses focused on vegetation patches (Bochet et al., 2006; Vásquez-Méndez et al., 2010); tree species with similar characteristics (Zhenlong et al., 2006; Zhang et al., 2014) and changes in land use from forest to cropping system and plantations (Daura, 1995; Eze, 1996; Haridjaja, 2012). These studies only consider mainly vegetation cover and did not assess the influence of vegetation characteristics on nutrient element loss. The present study therefore contributes 
an understanding in this regard by examining the influence of vegetation characteristics on nutrient loss in 3-year fallow and abandoned farmland in southern Nigeria.

\section{MATERIAL AND METHODS}

Study area: The study was carried out in Agoi-Ekpo, one of the villages in Yakurr Local Government Area of Cross River State. Its geographical coordinates are $5^{\circ} 50^{\prime} 0^{\prime \prime}$ North and $8^{\circ} 16^{\prime} 0^{\prime \prime}$ East (Maplandia.com 2005 cited in Iwara, 2013: 2018). The area lies within the Cross River plain. Agoi-Ekpo falls within the hotwet equatorial climate of the tropics. Vertisols are the main soils type found in the area. The geology/parent material is of cretaceous sediments (Oden et al. 2012). The area has luxuriant forest vegetation. The inhabitants are largely farmers, while teaching and civil service are the paramount white collar jobs (Iwara, 2013; 2014).

Site sampling and installation of runoff plots: Fallow of 3-year and abandoned farmland (with cassava) were identified and sampled using information on land use history provided by the local farmers. The 3-year fallow and abandoned farmland were used to estimate nutrient loss using runoff plot from which sediments were collected. All plots were in the same site, similar topography, and climate and soil types. In each study site, 10 plots of $20 \times 20 \mathrm{~m}$ were randomly established for the collection of vegetation data such as basal cover, girth, tree/shrub species composition, herbaceous cover, herbaceous species composition and litter depth. In the same way, a plot used for vegetation sampling for each fallow community was randomly selected from which the runoff plot was constructed for nutrient loss estimation. All plots were $10 \mathrm{~m}$ long and $4 \mathrm{~m}$ wide giving a total area of 40 sq. meters (0.004 hectare). At the tail end of each plot, a gutter for runoff collection was constructed at the outlet and storage container (.i.e. a 250-litre container drum) was installed to collect runoff after each rainstorm. The collection container was installed in a pit of $5 \mathrm{~m}$ by $5 \mathrm{~m}$ wide and $3.5 \mathrm{~m}$ deep. The PVC pipe performed the function of conveying the runoff and sediment into the collection container. The sediment that settled at the bottom of the container was obtained by adding some amount of the runoff water, rigorously stirred and collected in the plastic bucket. After which, the sediment was emptied into polythene bags with labels. The present study assessed nutrient losses from a fallow land and abandoned farmland from March 2012 to March 2013. However, analysis is done for 54 rainstorms with eroded sediment.

Laboratory analysis and estimation of nutrient loss: The air dried sediment was taken to the laboratory for analysis of organic carbon (OC), total nitrogen (TN), phosphorus $(\mathrm{P})$, calcium $(\mathrm{Ca})$, magnesium $(\mathrm{Mg})$, potassium $(\mathrm{K})$ and $\mathrm{Na}$ (sodium). These nutrients were analyzed because they are considered essential soil nutrients required by plant growth (Zekri and Obreza, 2012; Olson-Rutz and Jones, 2013). Organic carbon by the Walkley-Black method (1934); total nitrogen by the Kjeldahl method (Bremner and Mulvaney 1982); available phosphorus was determined by the method of Bray and Kurtz (1945). The soils were leached with $1 \mathrm{M}$ neutral ammonium acetate to obtain leachates used to determine exchangeable bases and soil cation exchange capacity, while $\mathrm{pH}$ values were determined using a glass electrode testronic digital $\mathrm{pH}$ meter with a soil: water ratio of $1: 2$. Nutrient loss in kilogramme per hectare $\left(\mathrm{kg} \mathrm{ha}{ }^{-1}\right)$ was estimated following the formula given by Ali et al., (2007) and Munodawafa (2012).

Vegetation estimation: Data on crown and basal cover were measured in percentages using the line intercept method (Coulloudon et al., 1999). Tree girth (tree size) was determined using diameter at breast height of $1.3 \mathrm{~m}$ from the ground (Kong et al., 2015), Girth measurement was done for plants regardless of tree or shrub species with diameter at breast height (dbh) $>0.10 \mathrm{~m}$. Herbaceous composition was determined using subplots of $1 \mathrm{~m}^{2}$ (Gilliam, 2007) On the other hand, litter depth in each plot was determined by measuring the amount of accumulated litter using a ruler and expressed in centimeters. It was achieved by dropping a ruler into the ground until a firm surface was reached. Tree/shrub species composition including cassava composition was obtained by counting the number of stems of individual species in each plot. Also, the line-intercept method was employed to estimate herbaceous cover. This was achieved by stretching a $20 \mathrm{~m}$ tape on each of the plot floor from which areas not covered by the plants (i.e. open spaces or gaps) were noted and then subtracted from the length of the tape, this gives the total area covered and then multiplied by 100 to give percentage of cover.

Soil sampling and laboratory analysis: Soil textural information of the 3-year fallow and abandoned farmland plots was determined by collecting topsoil samples $(0-15 \mathrm{~cm})$ using a soil auger. In each treatment, 5 vegetation plots were randomly selected from which surface $(0-15 \mathrm{~cm})$ soil samples were randomly collected. In all, 10 soil samples were collected, air-dried and taken to the laboratory for analysis of soil textural properties using the hydrometer method (Bouyoucos, 1926). 
Data analysis: Data on vegetation characteristics and nutrient losses were analysed and presented using tables, averages, independent samples test and stepwise multiple regression. Stepwise multiple regression analysis was used to build models in evaluating nutrient loss on the fallow vegetation. Stepwise method of regression analysis according to Attua (2009) is useful when trying to find the best subset of predictors. In essence, this technique selects most significant predictor variables contributing to the outcome/changes in the criterion variables. In this regard, the predictor variables in this study included tree/shrub density, density of herbs, vegetation cover, herbaceous cover, basal cover, tree size (girth) and litter depth as well as rainfall and runoff estimated from each plot treatment. On the other hand, nutrient loss parameters measured during the period of the experiment served as the criterion variables. The essence of adopting this statistical tool was to understand the interaction among the variables and to build explanatory models for modelling nutrient loss. Statistical analysis was carried out using the SPSS software (Version 22; SPSS; Chicago, IL, USA). The multiple regression model is mathematically defined as:

$Y=a+b_{1} X_{1}+b_{2} X_{2}+b_{3} X_{3}+b_{4} X_{4}+b_{5} X_{5} \ldots .+b_{8} X_{8}$

Where: $\mathrm{Y}=$ Criterion variable which is eroded nutrients (organic carbon, total nitrogen, phosphorus, calcium, magnesium, potassium and sodium; $a=\mathrm{Y}$ intercept; $b_{1}-b_{8}=$ Regression coefficients; $\mathrm{X}_{1}-\mathrm{X}_{8}=$ Predictor variables; $\mathrm{X}_{1}=$ Canopy cover $(\%) ; \mathrm{X}_{2}$ $=$ Tree/shrub species composition or density; $\mathrm{X}_{3}=$ Herbaceous composition; $\mathrm{X}_{4}=$ Girth $(\mathrm{m}) ; \mathrm{X}_{5}=$ Density of herbs or herbaceous density; $\mathrm{X}_{6}=$ Basal cover $(\mathrm{m}) ; \quad \mathrm{X}_{7}=$ Herbaceous cover; $\mathrm{X}_{8}=$ Litter depth $(\mathrm{m})$.

\section{RESULTS AND DISCUSSION}

Soil textural properties: Soil textural information of the 3-year fallow and abandoned farmland soils is depicted in Table 1. Sand content was comparatively high in the 3-year fallow, but low in the abandoned farmland with values of $63.0 \%$ and $60.6 \%$ respectively. This indicates that the soils of the fallow and abandoned farmland are principally sandy; with sand constituting more than $60 \%$ of the inorganic mineral fragment. Silt content in the treatments was relatively high in the abandoned farmland, followed by the 3 -year fallow with values of $23.0 \%$ and $22.2 \%$ respectively. In addition, clay proportion happened to be relatively high in the abandoned farmland and low in the 3-year fallow with values of $16.4 \%$ and $14.6 \%$ respectively (Table 1). Results of Independent Samples Test indicated that sand $(t=1.020, p>0.05)$, silt $(\mathrm{t}=0.305, \mathrm{p}>0.05)$ and clay $(\mathrm{t}=0.921, \mathrm{p}>0.05)$ contents do not differ between the plots. This implies that the soil of the fallow plot and cultivated farmland are similar. The textural analysis indicates that soils in the 3-year fallow and farmland are sandy loam with sand making up more than $60 \%$ of the inorganic mineral fragment. Sandy loam soils are known to be well-drained as such, soil erosion processes is expected to be minimal due to the appreciable amount of sand and silt compared to sandy clay soils. The obtained information on soil textural properties of the 3 -year fallow and farmland plots therefore indicates the soils are relatively similar which suggests that any difference in nutrient losses on the plot treatments may be attributed to the differences in vegetation characteristics.

\begin{tabular}{ccc}
\multicolumn{2}{c}{ Table 1: Physical properties (means \pm standard errors) } \\
\hline \multicolumn{2}{c}{ Soil } & \multicolumn{2}{c}{ Plots } \\
properties & 3-year & Abandoned farmland \\
\cline { 2 - 3 } & & $60.6 \pm 0.71$ \\
Sand (\%) & $63.0 \pm 2.25$ & $23.0 \pm 2.06$ \\
Silt (\%) & $22.2 \pm 1.62$ & $16.4 \pm 1.57$ \\
Clay (\%) & $14.8 \pm 0.75$ &
\end{tabular}

Floristic and structural pattern of vegetation: Table 2 shows results of the vegetation data. It showed that a mean value of 4 tree/shrub stands per plot was recorded on the 3-year fallow, while on the abandoned farmland with the inclusion of cassava stem; a mean value of 28 cassava/tree/shrub stands per plot were counted. Herbaceous composition was high on the 3year fallow and low on the abandoned farmland with mean values of 22 and 9 respectively. Crown cover with the inclusion of cassava stands and available trees was denser on the abandoned farmland than on the 3year fallow due to the widely spaced tree stands with mean values of $53.45 \%$ and $36.48 \%$ respectively. Litter depth was comparatively higher on the 3-year fallow than on the abandoned farmland with mean values of $2.52 \mathrm{~cm}$ and $1.11 \mathrm{~cm}$ respectively. The results simply show that basal cover, crown cover and tree density are higher on the abandoned farmland than on the 3-year fallow and this may have influence on nutrient loss. Results showed that vegetation characteristics differed significantly $(\mathrm{p}<0.01)$. The results therefore show that community composition and structure in the respective plots change with anthropogenic disturbance. This is consistent with the findings of Lalfakawma et al., (2009) that community composition changes with disturbance. The differences in vegetation characteristics between the 3 -year fallow and abandoned farmland indicate that the continuous cultivation of land for food crop cultivation results in the alteration of the forest vegetation. 
Table 2: Summary of vegetation characteristics across fallows

\begin{tabular}{llll}
\hline Parameters & \multicolumn{3}{l}{ Mean values } \\
\cline { 2 - 4 } & $\begin{array}{l}\text { 3-year } \\
\text { fallow }\end{array}$ & $\begin{array}{l}\text { Abandoned } \\
\text { farmland }\end{array}$ & t-value \\
\hline Crown cover (\%) & 36.48 & 53.45 & $33.787^{*}$ \\
Basal cover (\%) & 4.05 & 7.09 & $17.745^{*}$ \\
Girth (m) & 0.12 & 0.08 & $5.384^{*}$ \\
Litter depth (cm) & 2.52 & 1.11 & 60.644 \\
Herbaceous cover (\%) & 91.29 & 42.15 & $10.701^{*}$ \\
Trees/shrubs composition & 4 & 28 & $9.264^{*}$ \\
Herbaceous composition & 22 & 9 & $11.702^{*}$ \\
\hline
\end{tabular}

${ }^{*}$ Significant at $1 \%$ confidence level

Nutrient element losses: The amount of nutrient element losses in eroded sediment is presented in Table 3. It showed that the abandoned farmland experienced higher nutrient element losses than the 3 year fallow. For instance, the results showed that the abandoned farmland experienced higher OC loss than the 3 -year fallow with mean value of $3.73 \mathrm{~kg} / \mathrm{ha}$ and $1.47 \mathrm{~kg} / \mathrm{ha}$ respectively. As shown in the result, OC loss in eroded sediment was twice the amount or quantity eroded on the 3-year fallow. This was also the case with TN as the amount lost in eroded sediment was comparatively higher in the abandoned farmland than in the 3-year fallow with mean values of $0.87 \mathrm{~kg} / \mathrm{ha}$ and $0.35 \mathrm{~kg} / \mathrm{ha}$ respectively. The results in Table 3 therefore show that with the exception of $\mathrm{Ca}$ and $\mathrm{K}$, other nutrient element losses differed significantly between the treatments $(\mathrm{p}<0.05)$. The results show a clear difference in the amount of nutrient element losses between the plots. The study therefore shows that greater amount of the annual rainfall is absorbed by soils on the 3-year old fallow plot due to its dense herbaceous cover and developed root system. The differences in nutrient losses lend support to earlier and related studies, like those of Daura (1995), Vasquez-Mendez et al., (2010) and Iwara (2013: 2014) when they argued that land area covered with vegetation helps to reduce runoff and sediment loss.

Table 3: Summary of nutrient element losses

\begin{tabular}{llll}
\hline Nutrients & \multicolumn{3}{c}{ Mean values } \\
\cline { 2 - 4 } & 3-year & $\begin{array}{l}\text { Abandone } \\
\text { d farmland }\end{array}$ & t-value \\
\hline $\mathrm{OC}(\mathrm{kg} / \mathrm{ha})$ & 1.47 & 3.73 & $3.961^{*}$ \\
$\mathrm{TN}(\mathrm{kg} / \mathrm{ha})$ & 0.35 & 0.87 & $4.094^{*}$ \\
$\mathrm{Av} \mathrm{P}(\mathrm{g} / \mathrm{ha})$ & 0.06 & 0.21 & $5.957^{*}$ \\
$\mathrm{Ca}(\mathrm{Kg} / \mathrm{ha})$ & 0.48 & 0.86 & $1.909 \mathrm{~ns}$ \\
$\mathrm{Mg}(\mathrm{kg} / \mathrm{ha})$ & 0.22 & 0.47 & $3.168^{*}$ \\
$\mathrm{Na}(\mathrm{kg} / \mathrm{ha})$ & 0.08 & 0.17 & $4.581^{*}$ \\
$\mathrm{~K}(\mathrm{~kg} / \mathrm{ha})$ & 0.03 & 0.06 & $1.423 \mathrm{~ns}$ \\
\hline Significant at 5\% confidence level; ns =Insignificant at 5\% \\
\multicolumn{4}{c}{ confidence level }
\end{tabular}

Influence of vegetation characteristics on nutrient loss on the 3-year fallow: Out of the eleven soil nutrients, only calcium $(\mathrm{Ca})$, magnesium $(\mathrm{Mg})$ and potassium (K) were significantly influenced by a set of vegetation components (Table 4). Ca loss was best explained by basal cover. Basal cover was the only retained vegetation component that significantly explained 62.6 per cent of Ca loss on the 3-year fallow. Basal cover on the 3-year fallow was positively related to $\mathrm{Ca}$ loss. This positive association is expected considering the vegetation that characterized the 3year fallow (dominated by herbs with few shrubs). The dominance of herbs with shallow root system did not adequately loosen the soil layer to improve infiltration. Analysis of variance for the regression produced an Fratio of 13.362 which was significant at 0.01 confidence level (Table 4). In addition, for magnesium ( $\mathrm{Mg}$ ) loss, a model was produced and it identified basal cover as the significant vegetation component accountable for 57.2 per cent of Mg loss on the 3-year fallow. Basal cover on the 3-year fallow was positively related to $\mathrm{Mg}$ loss. Analysis of variance for the regression yielded an F-ratio of 10.700 which was significant at 0.01 confidence level (Table 4). Likewise, potassium (K) loss was explained by a single model and the model identified basal cover to the responsible for 52.7 per cent of $\mathrm{K}$ loss on the 3year fallow. Analysis of variance for the regression had an F-ratio of 8.899 which was significant at 0.01 confidence level (Table 4). Again, the sign of the regression coefficient revealed that $\mathrm{K}$ loss was positively related to basal cover. The result of stepwise regression analysis identified basal cover to be the principal vegetation variable responsible for nutrient element losses on the 3-year fallow. Basal cover was positively related to nutrient element losses. The basal cover on the 3-year fallow could not effectively control nutrient element losses because of the low density of tree/shrub caused by farming activities (slash, clear cutting and burning practice of land preparation) carried out before its abandonment. This affected the rapid establishment of shrubs which would have helped to loosen the soil to enhance infiltration through the development of deep root system. Thus, the shallow root system did not help to reduce runoff.

The results obtained show that vegetation characteristics play varying roles in minimizing nutrient element loss on the 3-year fallow. The ability of vegetation to control soil erosion and inherent nutrient element loss is dependent on the length of fallow and existence of dense herbaceous vegetation. The result shows that crown cover and basal cover on the 3-year fallow favoured erosional losses. The positive association between crown cover and erosional losses on the 3-year fallow is expected considering it low percentage of crown cover. This is so as the plot had low density of shrubs, and was dominated by herbaceous species like Chromolaena 
odorata as well as other herbaceous species like Centosema pubescens, Melanthera scandens and Costus afer. The shrub species on the 3-year fallow included Alchornea cordifolia, Harungana madagascariensis and Napoleona vogelii. In this regard, the crown cover provided by the widely spaced and few shrubs could not give the soil adequate cover against the erosive forces of raindrops. As such, it was ineffective in intercepting the rainwater. The destruction of trees during land preparation (slash, clear cutting and burning) greatly affects the crown cover percentage on the 3-year fallow plot making it inadequate in intercepting rainfall and minimizing runoff. The results obtained above are related to the finding of Bautista et al., (2007) that vegetation patches with low canopy cover experience increased runoff. The positive regression sign observed between basal cover and erosional losses (sediment and nutrient loss) is expected as the 3-year fallow plot was principally dominated by herbs with few stands of shrub species. This has implication on the structure of the basal cover and its ability to minimize runoff; as the stems of herbs did not develop deep root system that would have loosened the soil layer to facilitate infiltration. Hence, the shallow root system developed by the herbaceous species was ineffective to suppress erosional losses.

Influence of vegetation characteristics on nutrient loss on the abandoned farmland: On the abandoned farmland, crown cover was the only retained and significant vegetation component responsible for nutrient element losses. Out of the eleven soil nutrients, seven (7) notably OC, TN, Ca, Mg, K, Mn and $\mathrm{Fe}$ were significantly influenced by crown cover. The regression results of the respective nutrients are shown in the Table 5. Organic carbon (OC) loss on the abandoned farmland was best explained by crown cover, and it explained 59.1 per cent of the variability in OC. The sign of the regression coefficient revealed that OC loss on the abandoned farmland was positively related to crown cover. This implies increase in OC loss with the increase in crown cover. The analysis of variance result for the regression yielded an F-ratio of 11.574 which was statistically significant at 0.01 confidence level. For total nitrogen (TN) loss, crown cover was identified as the only significant vegetation component responsible for 59.9 per cent of TN loss on the abandoned farmland. The analysis of variance result for the regression produced an F-ratio of 11.945 which was statistically significant at 0.01 confidence level (Table 5).

Calcium (Ca) loss on the abandoned farmland was best explained by crown cover and it was accountable for 67.4 per cent of $\mathrm{Ca}$ loss. The analysis of variance result for the regression had an F-ratio of 16.539 which was statistically significant at 0.01 confidence level (Table 5). For magnesium $(\mathrm{Mg})$, crown cover was also accountable for 79.6 per cent of $\mathrm{Mg}$ loss. The analysis of variance result for the regression produced an Fratio of 31.084 which was statistically significant at 0.01 confidence level (Table 5). Also, crown cover best explained potassium (K) loss, and it was responsible for 82.3 per cent of $\mathrm{K}$ loss. The analysis of variance result for the regression produced an F-ratio of 37.083 statistically significant at 0.01 confidence level. The stepwise multiple regression result on the abandoned farmland therefore recognized crown cover as the sole vegetation component accountable for the varying quantities of nutrients eroded from the soils. The positive association observed between crown cover and the respective nutrient element losses is anticipated because the crown cover on the plot was sparse, as the plot was dominated by cassava. The cassava leaves could not afford the soil adequate cover. Also, the cassava leaves could not effectively intercept and diminish the erosive force of raindrops.

On the abandoned farmland, crown cover was the main contributor to the quantities of nutrient losses. The crown cover majorly provided by cassava leaves was ineffective to diminish the kinetic energy of rainwater mostly during periods of heavy rainstorms. Even with the rapid growth in cassava, erosion and its associated losses was still effective on the abandoned farmland. In an earlier study, Suyamto and Howeler (2001) opined that cassava is often blamed for causing severe soil erosion on farmland due to the wide spacing and its slow initial development. Suyamto and Howeler further observed that the long time it takes for the canopy to protect the soil from raindrop impact is another problem associated with cassava. This implies that cassava leaves do not help to reduce erosional losses on farmland which calls for a better land management practice. This further goes to reveal the consequences of felling trees during land preparation, as the practice prevents the soil of vegetative cover. This assertion is consistent with those of Pimentel and Burgess (2013) that the loss of vegetation soil cover is especially wide spread in developing countries where population is large and agricultural practices are often in adequate to protect the topsoil.

The few shrubs and trees found on the abandoned farmland like on the 3-year fallow are insufficient to provide adequate cover to the soil. This makes soil erosion to be high on the abandoned farmland. Pimentel (2006) observed that the extensive removal of forest for crops results in extensive soil erosion. The crown cover contributed by cassava leaves and tree/shrub canopy ranged from $51-57$ per cent. This 
is inadequate to prevent soil erosion. According to Haigh et al., (1995) in forested areas, a minimum of $60 \%$ forest cover is necessary to prevent serious soil erosion. Furthermore, on the abandoned farmland, nutrient element losses are best explained by basal cover. The positive regression sign indicates that basal cover is related to nutrient losses on the farmland. The basal cover on the farmland did not develop deep root system that would have loosened the soil layer to encourage infiltration. Since, the farmland was dominated by cassava; the basal cover was inadequate to effectively loosen the soil. The study therefore demonstrates the severity of soil erosion on fallow vegetation and the inefficiency of fallow with scanty vegetation in controlling soil erosion and restoring soil nutrient. Since, the results of nutrient loss underscore the relevance of basal cover, and crown cover in controlling erosional losses; to reduce the continuous loss of essential soil nutrient during natural fallowing, fallows with scanty vegetation mostly groundcover, girth, basal cover and litter depth should be properly managed through mulching.
Also, early cessation of weeding will help to provide cover to the soil during hash climatic condition and during the onset of the rains. Nevertheless, crown cover is not seen by this study as a significant vegetation component in suppressing soil erosion and its associated losses, Crown cover on the 3 -year and cultivated farmland shows positive regression sign and association with nutrient losses. This is not surprising, as crown cover alone does not afford the soil adequate protection against the degrading force of rainwater. Crown cover as noted by Lal (1995) cannot be compared to density of herbs (herbaceous cover). Lal argued that herbaceous cover is more effective in erosion control than tall canopies (crown cover) as a result of its effectiveness in breaking raindrop impact, traps transported soil particles and dissipates the energy of raindrop. This is evidently true as the low crown cover percentage on the 3-year and abandoned farmland was unable to suppress nutrient losses.

Table 4: Summary of stepwise multiple regression result of nutrient losses $(\mathrm{kg} / \mathrm{ha})$ with vegetation components on the 3-year fallow

\begin{tabular}{llllllll}
\hline $\begin{array}{l}\text { Independent } \\
\text { variable }(\mathbf{s})\end{array}$ & $\begin{array}{l}\text { Nutrient } \\
\text { loss }\end{array}$ & Intercept & $\begin{array}{l}\text { b } \\
\text { coefficient }\end{array}$ & $\begin{array}{l}\text { Std. } \\
\text { Error }\end{array}$ & $\begin{array}{l}\text { Multiple } \\
\text { R }\end{array}$ & $\begin{array}{l}\text { Level of } \\
\text { explanation }\end{array}$ & $\begin{array}{l}\text { t-value for } \\
\text { variables }\end{array}$ \\
\hline $\mathrm{BC}$ & $\mathrm{Ca}(\mathrm{kg} / \mathrm{ha})$ & -1.006 & 0.299 & 0.082 & 0.791 & $62.6 \%$ & $3.655^{*}$ \\
$\mathrm{BC}$ & $\mathrm{Mg}(\mathrm{kg} / \mathrm{ha})$ & -0.422 & 0.126 & 0.039 & 0.756 & $57.2 \%$ & $3.271+$ \\
$\mathrm{BC}$ & $\mathrm{K}(\mathrm{kg} / \mathrm{ha})$ & -0.074 & 0.022 & 0.008 & 0.726 & $52.7 \%$ & $2.983^{+}$ \\
\hline \multicolumn{2}{r}{ *Significant at 0.01 significance level; ${ }^{+}$Significant at 0.05 significance level, $\mathrm{BC}=$ basal cover $(\%)$}
\end{tabular}

Table 5: Summary of stepwise regression result of nutrient losses $(\mathrm{kg} / \mathrm{ha})$ with vegetation components on the abandoned farmland

\begin{tabular}{llllllll}
\hline $\begin{array}{l}\text { Independent } \\
\text { variable (s) }\end{array}$ & $\begin{array}{l}\text { Nutrient } \\
\text { loss }\end{array}$ & Intercept & $\begin{array}{l}\text { b } \\
\text { coefficient }\end{array}$ & $\begin{array}{l}\text { Std. } \\
\text { Error }\end{array}$ & $\begin{array}{l}\text { Multiple } \\
\text { R }\end{array}$ & $\begin{array}{l}\text { Level of } \\
\text { explanation }\end{array}$ & $\begin{array}{l}\text { t-value for } \\
\text { variables }\end{array}$ \\
\hline $\mathrm{CC}$ & $\mathrm{OC}(\mathrm{kg} / \mathrm{ha})$ & -24.165 & 0.490 & 0.144 & 0.769 & $59.1 \%$ & $3.402^{*}$ \\
$\mathrm{CC}$ & $\mathrm{TN}(\mathrm{kg} / \mathrm{ha})$ & -5.946 & 0.120 & 0.035 & 0.774 & $59.9 \%$ & $3.456^{*}$ \\
$\mathrm{CC}$ & $\mathrm{Ca}(\mathrm{kg} / \mathrm{ha})$ & -7.953 & 0.160 & 0.039 & 0.821 & $67.4 \%$ & $4.067^{*}$ \\
$\mathrm{CC}$ & $\mathrm{Mg}(\mathrm{kg} / \mathrm{ha})$ & -4.362 & 0.087 & 0.016 & 0.892 & $79.6 \%$ & $5.575^{*}$ \\
$\mathrm{CC}$ & $\mathrm{K}(\mathrm{kg} / \mathrm{ha})$ & -1.083 & 0.021 & 0.004 & 0.907 & $82.3 \%$ & $6.090^{*}$ \\
\hline \multicolumn{7}{c}{ *Significant at 0.01 significance level; ${ }^{+}$Significant at 0.05 significance level; CC = crown cover $(\%)$}
\end{tabular}

Conclusion: The study has shown that despite the existence of vegetation on the 3-year fallow and abandoned farmland, soil erosion still occurs even under appreciable vegetation and herbaceous cover resulting in the loss of nutrient-rich topsoil. It further shows that the quantities of nutrient element loss on the 3-year fallow decrease with the increase vegetation components. The result obtained implies that erosion resulting in nutrient loss is a serious problem especially on farmland as a result of sparse vegetation attributes caused by intensive cropping and farming activities. For rapid ecological restoration, trees and shrubs should not be completely cut down during land preparation, but should be pruned or allowed to grow on farmlands.

\section{REFERENCES}

Ali, I; Khan, F; Bhatti, AU (2007). Soil and nutrient losses by water erosion under mono-cropping and legume inter-cropping on sloping land. Pakistan J. Agric. Res., 20 (3 - 4): $161-166$.

Attua, EM (2009). Using multiple linear regression techniques to quantify carbon stocks of fallow vegetation in the tropics. West African Journal of Applied Ecology, 12: 1 - 7.

Bautista, S; Mayor, AG; Bourakhouadar, J; Bellot, J (2007). Plant spatial pattern predicts hillslope runoff and erosion in a semiarid Mediterranean landscape. Ecosystems 10, 987 - 998.

Bochet, E; Poesen, J; Rubio, JL (2006). Runoff and soil loss under individual plants of a semi-arid Mediterranean shrubland: influence of plant 
morphology and rainfall intensity. Earth Surface Processes and Landforms, 31 (5): 536 - 549.

Bouyoucos, GJ (1926). Hydrometer Method for Making Particle Size Analysis of Soils. Soil Science Society of America Proceedings, 26, 464465.

Bray, RH; Kurtz, LT (1945). Determination of total organic and available forms of phosphorus in soils. Soil Sci., 59, 39-48.

Bremner, JM; Mulvaney, CS (1982). "Nitrogen”, In Page, A. I., Miller, R. H. and Keeney, D. R. (eds.) The method of soil analysis: agronomy. Monogram, Madison: ASA.

Coulloudon, B; Eshelman, K; Gianola, J; Habich, N; Hughes, L; Johnson, C; Pellant, M. et al., (1999). Sampling vegetation attributes. Technical reference 1734-4, U.S. Department of Agriculture, Natural Resource

Conservation Service, Grazing Land Technology Institute. Retrieved 7th Nov., 2012 from: www. Blm.gov/nstc/library/pdf/samplveg.pdf

Daura, MM (1995). Comparative analysis of runoff, soil and nutrient loss under different cropping systems. Ph.D. Thesis, University of Ibadan, Nigeria.

Eze, BE (1996). Rain-splash detachment on different land use surfaces in a humid tropical environment: A Case of Ibadan Area. A Ph.D Thesis, University of Ibadan, Nigeria.

Gilliam, FS (2007). The ecological significance of the herbaceous layer in temperate forest ecosystems. BioScience, 57, no. 10, 845-858.

Haigh, MJ; Rawat, JS; Rawatc, MS; Bartarya, SK; Rai, SP (1995). Interactions between forest and landslide activity along new highways in the Kumaun Himalaya. For. Ecol. Manag, 78, 173189.

Haridjaja, O (2012). Sediment enrichment ratio and nutrient leached by runoff and soil erosion on cacao plantation. Journal of Tropical Soils, 17(1): 67-74.

Iwara, AI (2013). Runoff and soil loss of vegetative fallow and farmland of south-eastern Nigeria. Kasetsart J. (Natural Science), 47: 534 - 550.
Iwara, AI (2014). Evaluation of the variability in runoff and sediment loss in successional fallow vegetation of Southern Nigeria. Soil \& Water Resources, 9: 77-82.

Iwara, AI; Ewa, EE (2018). Seasonal variability in runoff, sediment and nutrient losses in vegetation fallows in the rainforest zone of southern Nigeria. Ghana Journal of Geography,10 (1): 42-57.

Iwara, AI; Ewa, EE; Njar, GN; Maduka, SO (2017). Relationships between vegetation characteristics and soil erosion in the rainforest zone of Southern Nigeria. Confluence Journal of Environmental Studies, 11(2): 27-36.

Kong, J; Ding, X; Liu, J; Yan, L; Wang, J (2015). New hybrid algorithms for estimating tree stem diameters at breast height using a two dimensional terrestrial laser scanner. Sensors, 15, 15661-15683.

Lal, R (1995). Sustainable management of soils in the humid tropics. United Nation University Press.

Lalfakawma; Sahoo, UK; Roy, S; Vanlalhriatpuia, K; Analalhluna, PCV (2009) Community composition and tree population structure in undisturbed and disturbed tropical semievergreen forest stands of north-east India. Applied Ecology and Environmental Research, 7(4): 303-318.

Munodawafa, A (2012). Quantifying nutrient losses with different sediment fractions under four tillage systems and granitic sandy soils of Zimbabwe. Retrieved 18 April 2014 from: http://dx.doi.org/10.5772/3402

Oden, MI; Okpamu, TA; Amah, EA (2012). Comparative analysis of fracture lineaments in Oban and Obudu Areas, SE Nigeria. J. Geography and Geology, 4 (2): 36-47.

Olson-Rutz, K; Jones, C (2013). Soil nutrient management for forages. Retrieved 25 April 2013 from:

http://landresources.montana.edu/soilfertility/PD Fbyformat/publication\%20pdfs/Forage_PKSM_ EB0217.pdf

Pimentel, D (2006). Soil erosion: a flood and environmental threat. Environment, Development \& Sustainability, 8: 119-137. 
Pimentel, D; Burgess, M (2013). Soil erosion threatens food production. Agriculture, 3, $443-463$.

Puigdefabregas, J (2005). The role of vegetation patterns in structuring runoff and sediment fluxes in Drylands. Earth Surface Processes and Landforms 30, 133-147.

Suyamto; Howeler, RH. (2001). "Cultural practices for soil erosion control in cassava-based cropping systems in Indonesia", In: Barker, D. H., Watson, A., Sombatpanit, S., Northcutt, B. and Maglinao, A. R. 2001. ground and water bioengineering for the Asia-Pacific Region.USA: Science Publishers Inc. info@scipub.net. Pp. 6 .

Vásquez-Méndez, R; Ventura-Ramos, E; Oleschko, K; Hernández-Sandoval, L; Parrot, JF; Nearing, MA (2010). Soil erosion and runoff in different vegetation patches from semi-arid Central Mexico. Catena, 80: 162-169.

Walkley, A; Black, IA (1934). An examination of the Detjareff method for determining soil organic matter and a proposed modification to the chromic acid titration method. Soil Science, 37, 29-38.
Wei, W; Chen, L; Fu, B; Huang, Z; Wu, D; Gui, L (2007). The effect of Land Uses and Rainfall Regimes on Runoff and Soil Erosion in the SemiArid Loess Hilly Area, China. Journal of Hydrology, 335: 247-258.

Wijitkosum, S (2012). Impacts of land use changes on soil erosion in $\mathrm{Pa}$ Deng sub-district, adjacent area of Kaeng Krachan National Park, Thailand. Soil and Water Research, 7: 10-17.

Zekri, M; Obreza, TA (2012). Plant nutrients for citrus trees. Retrieved 10 February 2013 from: http://edis.ifas.ufl.edu/pdffiles/SS/SS41900.pdf

Zhang, GH; Liu, GB; Zhang, PC; Yi, L (2014). Influence of vegetation parameters on runoff and sediment characteristics in patterned Artemisia capillaris plots. J. Arid Land, 6(3): 352-360.

Zhenhong, W; Chengbo, Y; Limei, Y; Zizong, Z; Jing, R; Li, Y; Ju, L (2006). Relationship and its ecological significance between plant species diversity and ecosystem function of soil conservation in semi-humid evergreen forests, Yunnan Province, China. J. Plant Ecology, 30 (3): 392-403. 